I nf I uence of drying temperat ure on the $\mathrm{migr}$ at i on of cesi umchl or i de i ni ti al I y di ssol ved i $n$ the I i qui d water of sugi ( Crypt omer i a j aponi ca D. Don) sapwood

\begin{tabular}{|c|c|}
\hline 著者 & $\begin{array}{l}\text { Tanaka Takashi, Mur akami Kaori, Kumat a } \\
\text { At sushi, Kawai Yasuo }\end{array}$ \\
\hline $\begin{array}{l}\text { jour nal or } \\
\text { publ i cat i on } \mathrm{title}\end{array}$ & Wbod Sci ence and Technol ogy \\
\hline vol une & 49 \\
\hline number & 5 \\
\hline page $r$ ange & $915-924$ \\
\hline year & $2015-06-29$ \\
\hline 出版者 & Spr i nger Ver I ag \\
\hline 権利 & $\begin{array}{l}\text { ( C) Spr i nger - Ver l ag Ber l i n Hei del berg } 2015 . \\
\text { The fi nal publ i cat i on i s avai I abl e at Spr i nger } \\
\text { vi a } \\
\text { ht t p: //dx. doi . or g/10. 1007/s00226-015-0746- } 4\end{array}$ \\
\hline URL & ht t p: //hdl . handl e. net /10297/9725 \\
\hline
\end{tabular}




\section{Influence of drying temperature on the migration of cesium chloride initially dissolved in the liquid water of sugi (Cryptomeria japonica D. Don) sapwood}

5 Takashi Tanaka ${ }^{1}{ }^{*}$, Kaori Murakami ${ }^{2}$, Atsushi Kumata ${ }^{3}$, Yasuo Kawai ${ }^{4}$

${ }^{1}$ Graduate School of Agriculture, Shizuoka University, Japan

${ }^{2}$ Fukushima Prefectural Forestry Research Centre, Japan

${ }^{3}$ Fukushima Prefectural Ken-nan Agriculture and Forestry Office, Japan

${ }^{4}$ Institute of Wood Technology, Akita Prefectural University, Japan

10

*Corresponding author.

Phone. +81-54-238-4860

Fax. $+81-54-238-4860$

attanak@ipc.shizuoka.ac.jp

15

Part of this article was presented at the 63rd Annual Meeting of the Japan Wood Research Society, Morioka, Japan, March 2013

Abstract: A method with potential utility in radiocesium decontamination from timber harvested in Fukushima region, where fallout from the Fukushima Daiichi nuclear disaster was deposited, involves drying the timber and planing away the contaminated wood. The objective of this study was to investigate the influence of drying temperature on the migration of cesium dissolved in the liquid water of sugi (Cryptomeria japonica D. Don) sapwood during the drying process. Small specimens of sugi sapwood impregnated with aqueous cesium chloride $(\mathrm{CsCl})$ solution were dried at $20^{\circ} \mathrm{C}$ or $90{ }^{\circ} \mathrm{C}$, and the migration of $\mathrm{CsCl}$ during drying was examined by means of X-ray imaging. The results of this study indicate that the drying of sugi sapwood at any temperature causes surface accumulation of dissolved cesium, which is affected by both the drying temperature and grain orientation of the surface. Statistical analysis confirmed that a high drying temperature causes greater surface accumulation of $\mathrm{CsCl}$ during drying. We recommend using higher temperatures to dry sugi sapwood when employing the drying/planing method for radiocesium decontamination from timber.

Keywords: cesium chloride $(\mathrm{CsCl})$, drying temperature, Japanese cedar, redistribution during drying, X-ray imaging 


\section{Introduction}

Radiocesium contamination of forest and forest products after the Fukushima Daiichi nuclear disaster in

March 2011 remains an environmental concern in Japan. Fallout radiocesium entered trees of the surrounding

regions through direct deposition of atmospheric radiocesium onto tree surfaces and uptake from the soil via the

roots (Hasegawa et al. 2009). Radiocesium is therefore detected not only in the bark but also in sapwood and

heartwood (Kuroda et al. 2013). Approximately 50-90\% of radiocesium in aerosols is water soluble (Tanaka et

al. 2013) and thus is partly dissolved in the tree sap.

A brown discoloration (kiln brown stain), which causes quality defects, often develops approximately 1

mm under the timber surface after kiln drying (Kreber and Haslett 1997). This discoloration is attributed to a

10 kiln-drying-induced gradient of soluble nitrogenous or carbohydrate compounds from the inside to the surface

(King et al. 1974, Terziev et al. 1993, Theander et al. 1993, Terziev 1995). Based on a simulation with a

percolation model, Salin (2008a) demonstrated that kiln brown stain results from the accumulation of a

discoloration-inducing substance dissolved in the liquid water of sapwood indicating that the movement of free

water in wood during drying causes the migration of dissolved substances from the inside to the surface. Tanaka

and Kawai (2014) conducted the drying experiment with small sugi specimens soaked with a CsCl solution, and

used X-ray imaging to visualize the inside-to-surface migration of dissolved $\mathrm{CsCl}$ in the liquid water of the wood.

Their data indicate that $\mathrm{CsCl}$ initially dissolved in the liquid water of wood migrates from inside to the surface

during the kiln drying of $65^{\circ} \mathrm{C}$ especially in sapwood. Thus, the concentration of $\mathrm{CsCl}$ inside samples seems to

have decreased by half after the sapwood is dried. These results suggest that drying and planing the timber, 
especially sapwood, harvested in the Fukushima regions before commercialization can successfully

decontaminate it of radiocesium. Fortunately, the radiocesium concentration in heartwood is lesser than that in sapwood (Kuroda et al. 2013). Thus, we consider that this method has potential for the decontamination of sawn timber in Fukushima.

Kreber and Haslett (1997) have reported that the formation of kiln brown stain is intensified with a higher

drying temperature. Given that radiocesium in wood exhibits a similar migratory behavior, lumber

decontamination by drying and planing should become more efficient with a higher drying temperature. Thus,

the objective of this study was to investigate the influence of drying temperature on the migration of $\mathrm{CsCl}$ in the liquid water of sugi sapwood during drying. To this purpose, sugi sapwood impregnated with $\mathrm{CsCl}$ aqueous solution was dried at different temperatures, and the migration of $\mathrm{CsCl}$ was observed by means of $\mathrm{X}$-ray imaging.

The distribution of $\mathrm{CsCl}$ in wood samples was evaluated at the end of drying and the effect of drying temperature on the formation of surface deposition during drying was statistically analyzed.

\section{Materials and methods}

were cut from three air-dried tree trunks (Table 1) with a circular table saw. Six samples were soaked in an aqueous solution of $3 \% \mathrm{CsCl}$, and the other six were soaked in distilled water (control samples). The samples were intermittently exposed to lower pressure $(10 \mathrm{kPa})$ to saturate them with the solutions. The saturated samples were then softly wiped with cleaning tissues. 
An X-ray machine (SR-1010, Softex Co., Ltd., Ebina, Japan) equipped with a digital X-ray sensor (NX-04H, Softex Co., Ltd., Ebina, Japan) was used to scan the samples from three different directions (40-kVp tube voltage, 14-mA tube current, 1.0-mm-thick aluminum filter). Samples were exposed for $1 \mathrm{~s}$, and the scanned image was saved in the ".dcm" file format at a resolution of $5340 \times 5000$ pixels $\left(20\right.$ pixel mm m $\left.^{-1}\right)$ in 12 -bit (0-4095) grayscale.

Three CsCl-soaked samples and three control samples were then dried in a conditioning chamber at $20^{\circ} \mathrm{C}$ and $65 \%$ relative humidity. The samples were removed from the chamber after $40,130,230,350,530$, and 1410 min of drying, scanned as described above, and then immediately placed back into the chamber. Experiments were stopped after 1410 min of drying, when the weights of samples soaked with distilled water were lower than their corresponding air-dry weights.

The remaining samples were dried in a conditioning chamber at the dry-bulb temperature of $90^{\circ} \mathrm{C}$ and $26 \%$ relative humidity $\left(60^{\circ} \mathrm{C}\right.$ wet-bulb temperature). The samples were removed from the chamber after 10,25 , $40,60,85$, and 125 min of drying, scanned as described before, and then immediately placed back into the chamber. Experiments were stopped after 125 min of drying, when the weights of samples soaked with distilled water were lower than their air-dry weights.

Equation 1, which was derived experimentally from 14 poly(methyl methacrylate) (PMMA) plates of various thicknesses (1.0-30 mm) by Tanaka and Kawai (2014), was used to calculate PMMA-equivalent-thickness distributions (PMMA-EThD, $y$ ) to the brightness value $(x)$ for all X-ray images.

$$
y=-26.65 \ln x+209.12 \quad(\text { Eq. } 1)
$$


The PMMA-EThD value before soaking was subtracted from the corresponding value after drying to calculate the net change in PMMA-EThD. To avoid sample deformation during drying, images were registered in ImageJ 1.45s (Wayne Rasband, National Institute of Health, USA) and its extension bUnwarpJ 2.6 (Ignacio Arganda-Carreras, Massachusetts Institute of Technology) before subtracting. Because Cs attenuates X-rays

predominantly reflect the concentration distribution of deposited $\mathrm{CsCl}$. To compare the concentration distribution of deposited $\mathrm{CsCl}$ with that of the initially dissolved $\mathrm{CsCl}$, the PMMA-EThD in each pixel was divided by the average value of the change in PMMA-EThD.

To determine whether the drying temperature affected the average surface $\mathrm{CsCl}$ concentration, analysis of variance (ANOVA) was conducted on the average $\mathrm{CsCl}$ concentrations at $0-1 \mathrm{~mm}$ below the surface obtained at three different drying temperatures, $20^{\circ} \mathrm{C}, 65^{\circ} \mathrm{C}$, and $90^{\circ} \mathrm{C}$, each consisting of three data points (three specimens). The $65{ }^{\circ} \mathrm{C}$ data points were extracted from the original data of the previous study (Tanaka and Kawai 2014).

\section{Results and discussion}

Figure 1 shows the X-ray images of the tangential surface of the samples during drying. As expected, a

sharp contrast between the surface and subsurface of wood gradually developed during drying in the samples

soaked with $\mathrm{CsCl}$ solution in both the drying conditions. On the other hand, no contrast developed between the surface and subsurface in samples soaked with distilled water, indicating that the substance providing X-ray contrast was $\mathrm{CsCl}$. These results are consistent with those of the previous study (Tanaka and Kawai 2014), 
confirming that the drying of sugi sapwood at any temperature causes the surface accumulation of dissolved

$\mathrm{CsCl}$ during drying.

Figure 2 shows the changes of brightness profiles (over the lines $T_{1}, L_{1}, T_{2}$ and $L_{2}$ drawn in Figure 1)

during drying in the control samples, which indicated no significant differences between drying at $20{ }^{\circ} \mathrm{C}$ and 90

${ }^{\circ} \mathrm{C}$ in the formation or change of a brightness profile during the process. This suggests that the drying

temperature has no significant impact on how liquid water moves in sugi sapwood during drying, except for the

total amount of drying time required. Interestingly, we demonstrated a phenomenon in which the liquid water at

the center part of the sample decreased more rapidly than that in the other parts, thereby producing a double-peak

in the water distribution along the lines $\mathrm{L}_{1}$ and $\mathrm{L}_{2}$ in Figure 2 during drying. Although it is well known that

10 sapwood drying above the fiber saturation point is usually gradient-free (Wiberg 1995, Wiberg and Morén 1999),

to the best of our knowledge, the "inverse gradient" drying observed in the present study has not been reported

before. Further investigation is needed to elucidate this phenomenon. On the other hand, for samples soaked with

a $\mathrm{CsCl}$ aqueous solution, drying at $90{ }^{\circ} \mathrm{C}$ caused a greater difference in brightness between the surface and

subsurface at the end of drying (Fig. 3). This result indicates that drying at $90{ }^{\circ} \mathrm{C}$ enhanced the migration of $\mathrm{CsCl}$

15 from the inside to the surface of sugi sapwood.

We also analyzed the relative concentration distribution of $\mathrm{CsCl}$ in samples at the end of the drying

process compared to that of initially dissolved $\mathrm{CsCl}$ (Figure 4). Overall, $90{ }^{\circ} \mathrm{C}$ drying showed a broader

distribution of $\mathrm{CsCl}$ accumulation (> 300\% concentration increase, as indicated in red in the heat maps; Fig. 4).

This indicates that the higher drying temperature intensified the accumulation of $\mathrm{CsCl}$ just below the surface. 
This is in agreement with the finding that kiln brown stain formation is also intensified with a higher drying

temperature (Kreber and Haslett 1997).

Figure 5 illustrates the relationship between drying temperature and relative $\mathrm{CsCl}$ concentration in the 1-mm-thick surface layers, which were calculated by determining average $\mathrm{CsCl}$ concentrations at $0-1 \mathrm{~mm}$ below the surface (Figure 4). The $65^{\circ} \mathrm{C}$ data points included in the figure are extracted from the original data of the previous report (Tanaka and Kawai 2014). In tangential surfaces, the surface accumulation of CsCl developed similarly regardless of drying temperature. By contrast, the surface accumulation of $\mathrm{CsCl}$ at $65{ }^{\circ} \mathrm{C}$ drying was minimum in radial surfaces, whereas maximum in cross-sectional surfaces. These results indicate that the grain direction affects the variation of the surface accumulation of $\mathrm{CsCl}$ with the increased drying temperature. One reason for this directionality could be the quite low permeability of sugi in the radial direction. Indeed, considering that sugi is one of the least radially permeable softwoods (Tanaka et al. 2015), different results may be observed in other species. In addition, green sugi wood has fewer aspirated pits (Matsumura et al. 2005) than dried sugi wood; therefore, the drying of green sugi sapwood may also lead to a different outcome (presumably to more migration in the radial direction).

calculated by averaging the three data points (tangential, radial, and cross-section surfaces) shown in Figure 5.

To determine whether the drying temperature affected the average surface $\mathrm{CsCl}$ concentration, ANOVA was performed between the three temperature groups $20^{\circ} \mathrm{C}, 65^{\circ} \mathrm{C}$, and $90^{\circ} \mathrm{C}$, each consisting of three data points (three specimens). The calculated $\mathrm{F}$ value (Table 2) was larger than the 5\% significance level threshold value 
5.143, indicating that the average relative $\mathrm{CsCl}$ concentration was significantly $(p<0.05)$ influenced by the drying temperature. These results shown in Figure 5 and Table 2 support the idea that a higher drying temperature intensifies the surface accumulation of $\mathrm{CsCl}$ initially dissolved in liquid water in sugi sapwood. Considering the concentration of $\mathrm{CsCl}$ inside samples reduced to approximately $50 \%$ of the initial $\mathrm{CsCl}$ concentration by the kiln drying at $65^{\circ} \mathrm{C}$ (Tanaka and Kawai 2014), a drying temperature higher than $65^{\circ} \mathrm{C}$ may achieve the removal of more than $50 \% \mathrm{CsCl}$ after drying and planing. A possible mechanism for this phenomenon involves the lower surface tension of liquid water at higher temperatures, which allows liquid water to migrate against capillary forces in tracheids.

When modeling the surface accumulation of dissolved substances during drying, more accurate data can be obtained by taking into account the drying temperature, in addition to pore-network and percolation processes (Salin 2006a, Salin 2006b, Salin 2008a) and physical damage to the surface layers (Salin 2008b).

The findings of this study are encouraging for the success of using drying and planing of Fukushima-sourced timber as a method of radiocesium decontamination, in that a higher temperature drying process presumably increase the amount of radiocesium removed during planing. However, our study findings reflect cubic wood specimens. Further investigation is needed to clarify the influence of the shape of sawn timber on the surface concentration. In fact, our future studies include conducting an experiment with actual size, radiocesium-contaminated timber, while utilizing a high temperature drying process.

\section{Conclusions}


The results of this study indicate that the drying of sugi sapwood at any temperature causes the surface accumulation of dissolved $\mathrm{CsCl}$ during drying, and that both drying temperature and grain direction of the surface affect the degree of surface accumulation. Overall, on all surface averages, a higher drying temperature induced greater surface accumulation of $\mathrm{CsCl}$ during drying. Thus, we recommend that when the proposed 5 method of drying and planing of Cs-contaminated timber is to be tried for radiocesium contamination, a suitably high drying temperature should be utilized to improve the process.

Acknowledgments: This work was supported by JSPS KAKENHI Grant Number 24780170 and LIXIL JS Foundation Research Grant No. 12-66. We thank Drs. Katsuhiko Takata and Shigeru Yamauchi at Akita

10 Prefectural University for donating sugi samples and providing $\mathrm{CsCl}$, respectively. 


\section{References}

Hasegawa H, Tsukada H, Kawabata H, Chikuchi Y, Takaku Y, Hisamatsu S (2009) Effect of the counter anion of cesium on foliar uptake and translocation. J Environ Radioactivity 100:54-57

Hubbell JH, Seltzer SM (2004) Tables of X-Ray Mass Attenuation Coefficients and Mass Energy-Absorption

Ida T (2008) How to use powder diffraction method (2) - Preparation of Specimen - (in Japanese). J Flux

\section{Growth 3:2-6}

King B, Oxley TA, Long KD (1974) Soluble nitrogen in wood and its redistribution on drying. Material

Organismen 9:241-254

10 Kreber B, Haslett AN (1997) A study of some factors promoting kiln brown stain formation in radiata pine. Holz Roh-Werkst 55:215-220

Kuroda K, Kagawa A, Tonosaki M (2013) Radiocesium concentrations in the bark, sapwood and heartwood of three tree species collected at Fukushima forests half a year after the Fukushima Dai-ichi nuclear accident. J Environ Radioactivity 122:37-42

Matsumura J, Yamasaki Y, Oda K, Fujisawa Y (2005) Profile of bordered pit aspiration in Cryptomeria japonica using confocal laser scanning microscopy: pit aspiration and heartwood color. J Wood Sci 51:328-333

Salin JG (2006a) Modelling of the behaviour of free water in sapwood during drying. Part 1. A new percolation approach. Wood Mater Sci Eng 1:4-11

Salin JG (2006b) Modelling of the behaviour of free water in sapwood during drying. Part 2. Some simulation 
results. Wood Mater Sci Eng 1:45-51

Salin JG (2008a) Drying of liquid water in wood as influenced by the capillary fiber network. Drying Technol 26:560-567

Salin JG (2008b) Almost all wooden pieces have a damaged surface layer-Impact on some properties and quality. Proceedings of the European COST Action E53 Conference. Delft, Netherlands, pp. 135-143

Tanaka K, Sakaguchi A, Kanai Y, Tsuruta H, Shinohara A, Takahashi Y (2013) Heterogeneous distribution of radiocesium in aerosols, soil and particulate matters emitted by the Fukushima Daiichi Nuclear Power Plant accident: retention of micro-scale heterogeneity during the migration of radiocesium from the air into ground and river systems. J Radioanal Nucl Chem 295:1927-1937

Tanaka T, Kawai Y (2014) Migration of cesium chloride dissolved in the liquid water of sugi (Cryptomeria japonica D. Don) during drying at $65^{\circ} \mathrm{C}$. Holzforschung 68(5): 591-597

Tanaka, T., Kawai, Y., Sadanari, M., Shida, S., Tsuchimoto, T. (2015) Air permeability of sugi (Cryptomeria japonica) wood in the three directions. Maderas. Ciencia y Tecnología 17(1), 17-28

Terziev N, Boutelje J, Söderström O (1993) The influence of drying schedules on the redistribution of low-molecular sugars in Pinus sylvestris L. Holzforschung 47:3-8

Terziev N (1995) Migration of low-molecular sugars and nitrogenous compounds in Pinus sylvestris L. during kiln and air drying. Holzforschung 49:565-574

Theander O, Bjurman J, Boutelje JB (1993) Increase in the content of low-molecular carbohydrates at lumber surfaces during drying and correlations with nitrogen content, yellowing and mould growth. Wood Sci 
Technol 27:381-389

Wiberg P (1995) Moisture distribution changes during drying. Holz Roh- Werkst 53:402

Wiberg P, Morén TJ (1999) Moisture flux determination in wood during drying above fibre saturation point using CT-scanning and digital image processing. Holz Roh-Werkst 57:137-144 
Table 1. Density and number of annual rings of the testing samples of different origins.

\begin{tabular}{|c|c|c|c|c|c|}
\hline $\begin{array}{l}\text { Tree and } \\
\text { tree origin }\end{array}$ & $\begin{array}{l}\text { Sample } \\
\text { no. }\end{array}$ & $\begin{array}{c}\text { Density at } \\
\left(20^{\circ} \mathrm{C}\right. \\
65 \% \mathrm{RH})\end{array}$ & $\begin{array}{l}\text { Number } \\
\text { of annual } \\
\text { rings }\end{array}$ & $\begin{array}{l}\text { Solution for } \\
\text { soaking }\end{array}$ & $\begin{array}{l}\text { Drying temperature and } \\
\text { relative humidity }\end{array}$ \\
\hline \multirow[t]{4}{*}{ Tree $1^{a}$} & 1s_Cs20 & 0.39 & 7 & CsCl aq. sol. & $20^{\circ} \mathrm{C}, 65 \%$ \\
\hline & 1s_w20 & 0.40 & 7 & Distilled water & \\
\hline & 1s_Cs90 & 0.43 & 9 & CsCl aq. sol. & $90{ }^{\circ} \mathrm{C}, 26 \%$ \\
\hline & 1s_w90 & 0.42 & 9 & Distilled water & (Wet-bulb temperature: $60^{\circ} \mathrm{C}$ ) \\
\hline \multirow[t]{4}{*}{ Tree $2^{\mathrm{a}}$} & 2s_Cs20 & 0.42 & 8 & CsCl aq. sol. & $20{ }^{\circ} \mathrm{C}, 65 \%$ \\
\hline & 2s_w20 & 0.42 & 7 & Distilled water & \\
\hline & 2s_Cs90 & 0.38 & 9 & CsCl aq. sol. & $90{ }^{\circ} \mathrm{C}, 26 \%$ \\
\hline & 2s_w90 & 0.40 & 7 & Distilled water & (Wet-bulb temperature: $60^{\circ} \mathrm{C}$ ) \\
\hline \multirow[t]{4}{*}{ Tree $3^{\mathrm{a}}$} & 3s_Cs20 & 0.36 & 6 & CsCl aq. sol. & $20^{\circ} \mathrm{C}, 65 \%$ \\
\hline & 3s_w20 & 0.42 & 6 & Distilled water & \\
\hline & 3s_Cs90 & 0.39 & 5 & CsCl aq. sol. & $90{ }^{\circ} \mathrm{C}, 26 \%$ \\
\hline & 3s_w90 & 0.37 & 5 & Distilled water & (Wet-bulb temperature: $60^{\circ} \mathrm{C}$ ) \\
\hline
\end{tabular}

${ }^{a}$ Semboku, Akita prefecture (plantation forest), approximately 50 year old trees. 
Table 2. ANOVA of the relationship between drying temperature and relative $\mathrm{CsCl}$ concentration in the 1-mm-thick surface layers.

\begin{tabular}{lccccc}
\hline $\begin{array}{c}\text { Source of } \\
\text { variation }\end{array}$ & $\begin{array}{c}\text { Sum of } \\
\text { squares }\end{array}$ & $\begin{array}{c}\text { Degrees of } \\
\text { freedom }\end{array}$ & $\begin{array}{c}\text { Mean of } \\
\text { squares }\end{array}$ & $\begin{array}{c}\text { F } \\
\text { value }\end{array}$ & $\begin{array}{c}\text { Significance } \\
\text { level }^{*}\end{array}$ \\
\hline $\begin{array}{l}\text { Temperature } \\
\text { factor }\end{array}$ & 481.4 & 2 & 240.7 & 9.408 & 5.143 \\
(Between-group) & & & & & \\
\hline $\begin{array}{l}\text { Error } \\
\text { (Within-group) }\end{array}$ & 153.5 & 6 & 25.6 & & \\
\hline Total & 634.9 & & & & \\
\hline
\end{tabular}

* represents significance level of $p<0.05$ 


\section{Figure captions}

Fig. 1 X-ray images of tangential surfaces of the testing samples during drying. The vertical and horizontal directions of each image represent the longitudinal and tangential directions of each sample, respectively. The white lines $\left(\mathrm{T}_{1-4}, \mathrm{~L}_{1-4}\right)$ represent the tangential $(\mathrm{T})$ and longitudinal $(\mathrm{L})$ lines over which brightness profiles were measured

Fig. 2 Changes in brightness profiles along lines $\mathrm{T}_{1}, \mathrm{~L}_{1}, \mathrm{~T}_{2}$ and $\mathrm{L}_{2}$ in Figure 1 (samples soaked with distilled water) during drying at 20 and $90^{\circ} \mathrm{C}$

Fig. 3 Changes in brightness profiles along lines $\mathrm{T}_{3}, \mathrm{~L}_{3}, \mathrm{~T}_{4}$ and $\mathrm{L}_{4}$ in Figure 1 (samples soaked with a CsCl solution) during drying at 20 and $90^{\circ} \mathrm{C}$

10 Fig. 4 Relative $\mathrm{CsCl}$ concentrations at the end of drying at $20{ }^{\circ} \mathrm{C}$ and $90{ }^{\circ} \mathrm{C}$ compared with initial $\mathrm{CsCl}$ concentrations, with the heat map describing more intense concentrations of $\mathrm{CsCl}$ deposition at the red end of the provided spectrum

Fig. 5 Relationship between drying temperature and relative $\mathrm{CsCl}$ concentration in the 1-mm-thick surface layers. ${ }^{a}$ indicates data points from the previous study by Tanaka and Kawai (2014) 


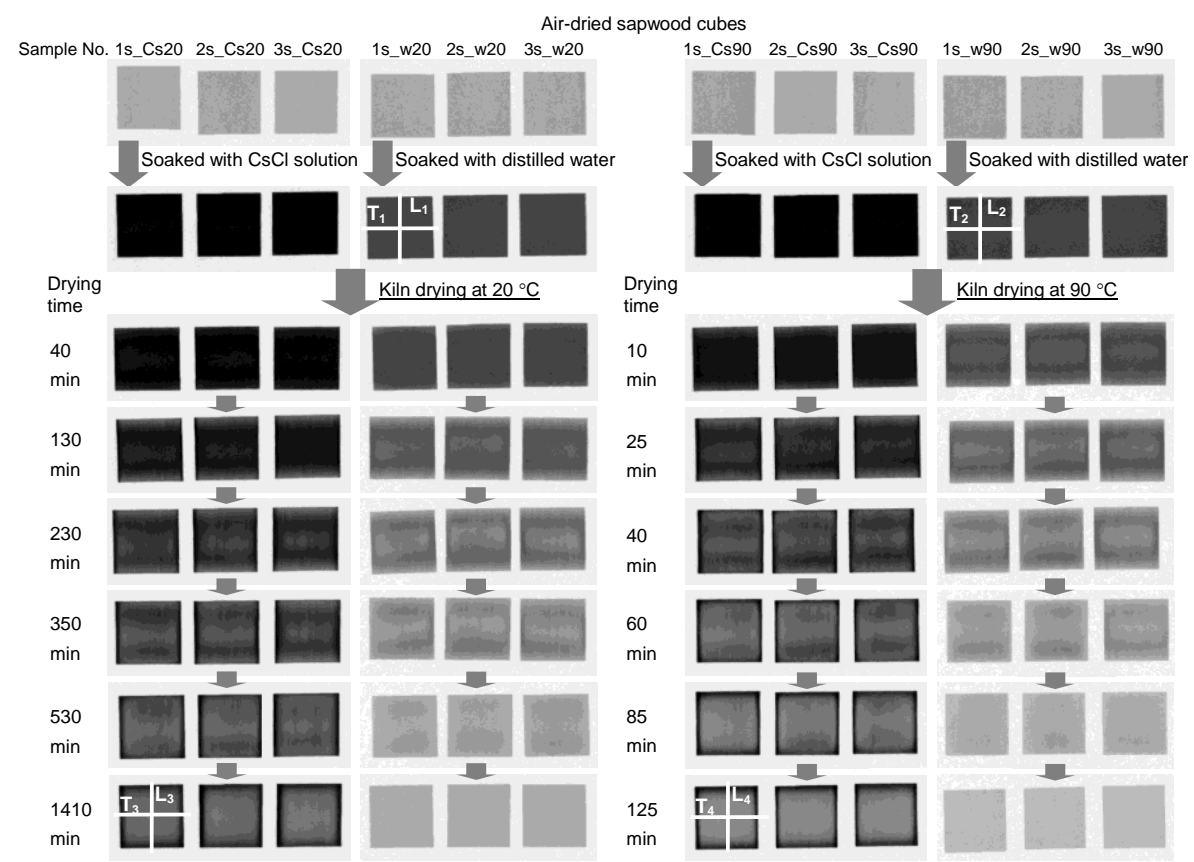

Fig. 1 X-ray images of tangential surfaces of the testing samples during drying. The vertical and horizontal directions of each image represent the longitudinal and tangential directions of each sample, respectively. The white lines $\left(\mathrm{T}_{1-4}, \mathrm{~L}_{1-4}\right)$ represent the tangential $(\mathrm{T})$ and longitudinal $(\mathrm{L})$ lines over which brightness profiles were measured 

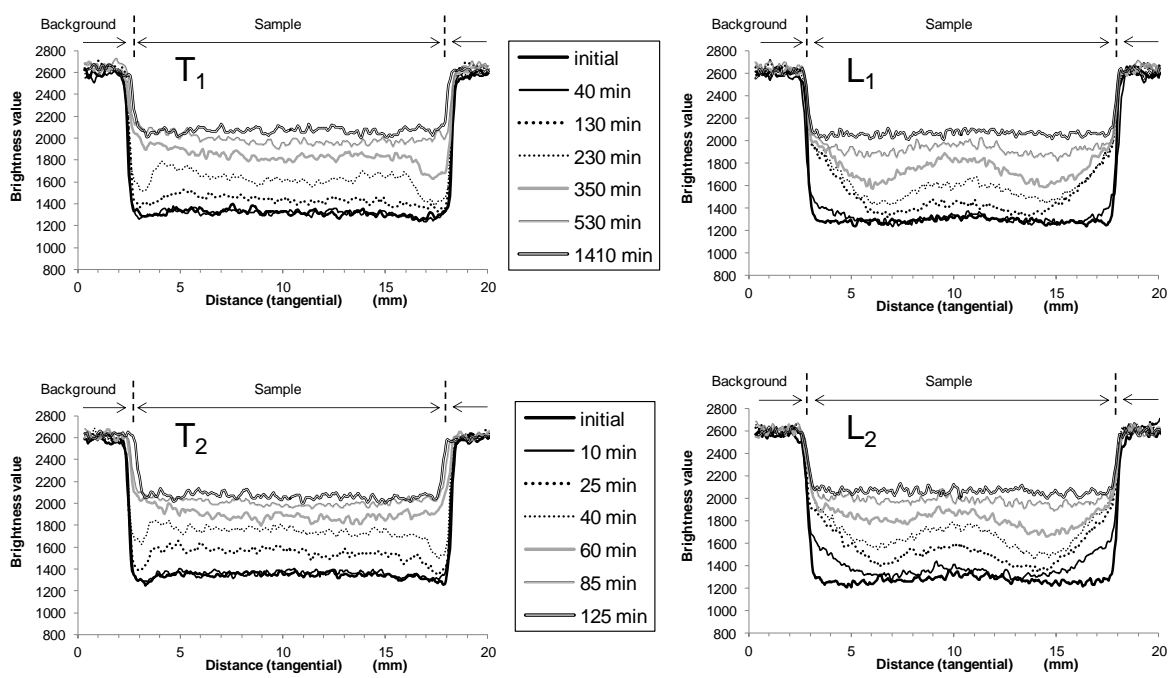

Fig. 2 Changes in brightness profiles along lines $\mathrm{T}_{1}, \mathrm{~L}_{1}, \mathrm{~T}_{2}$ and $\mathrm{L}_{2}$ in Figure 1 (samples soaked with distilled water) during drying at 20 and $90^{\circ} \mathrm{C}$ 

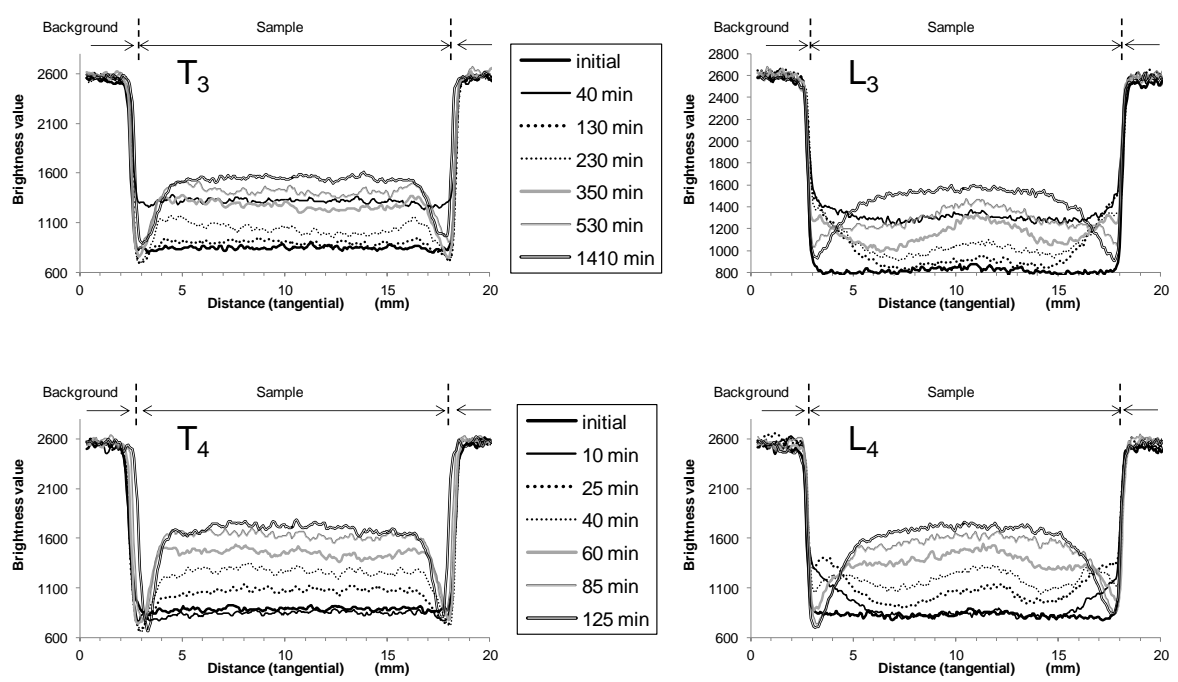

Fig. 3 Changes in brightness profiles along lines $T_{3}, L_{3}, T_{4}$ and $L_{4}$ in Figure 1 (samples soaked with a $\mathrm{CsCl}$ solution) during drying at 20 and $90^{\circ} \mathrm{C}$ 


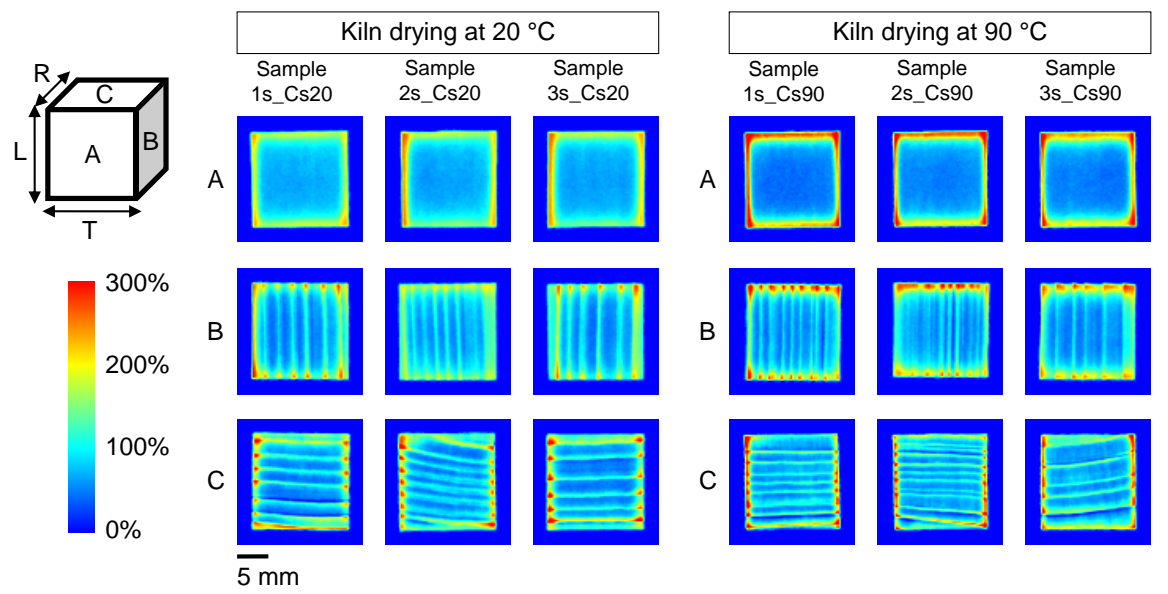

Fig. 4 Relative $\mathrm{CsCl}$ concentrations at the end of drying at $20{ }^{\circ} \mathrm{C}$ and $90{ }^{\circ} \mathrm{C}$ compared with initial $\mathrm{CsCl}$ concentrations, with the heat map describing more intense concentrations of $\mathrm{CsCl}$ deposition at the red end of the provided spectrum 


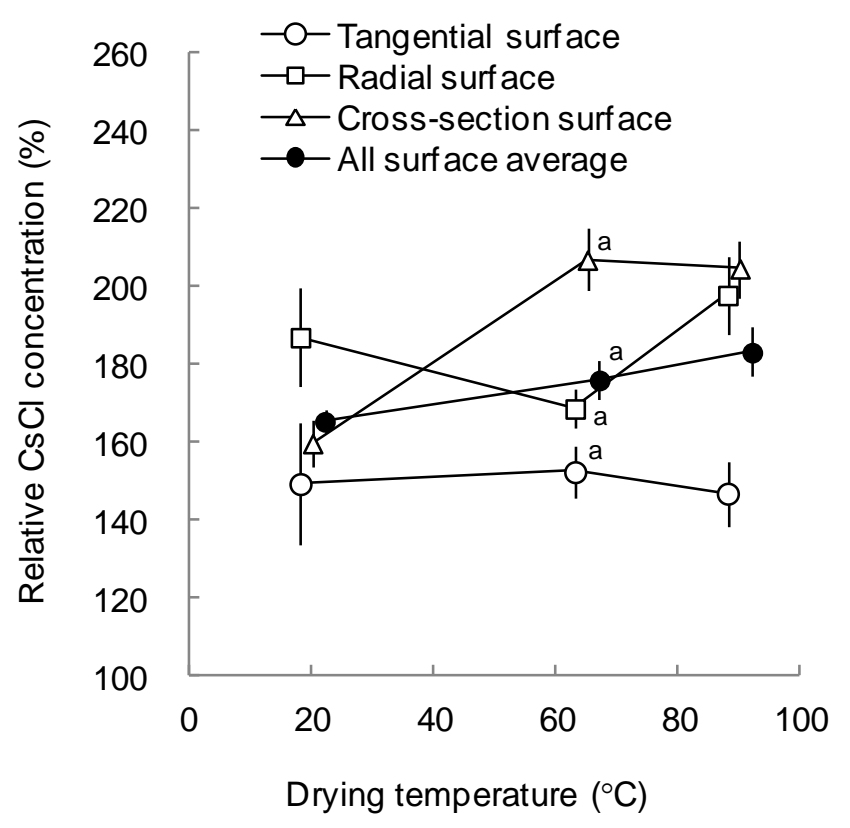

Fig. 5 Relationship between drying temperature and relative $\mathrm{CsCl}$ concentration in the 1-mm-thick surface layers. ${ }^{a}$ indicates data points from the previous study by Tanaka and Kawai (2014) 